\title{
Effects of urbanization on the fauna of Odonata on the coast of southern Brazil
}

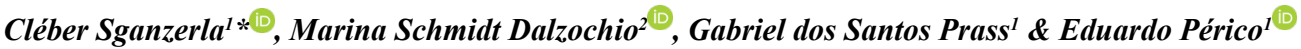 \\ ${ }^{1}$ Universidade do Vale do Taquari, Laboratório de Ecologia e Evolução, Lajeado, RS, Brasil. \\ ${ }^{2}$ Universidade Feevale, Convênio de Prevenção e Combate à Dengue, Novo Hamburgo, RS, Brasil. \\ ${ }^{*}$ Corresponding author: Cléber Sganzerla, e-mail: clebersganzerla1@gmail.com
}

\begin{abstract}
SGANZERLA, C., DALZOCHIO, M.S., PRASS, G.S., PÉRICO, E.. Effects of urbanization on the fauna of Odonata on the coast of southern Brazil. Biota Neotropica 21(1): e20201122. https://doi.org/10.1590/16760611-BN-2020-1122
\end{abstract}

\begin{abstract}
Urbanization significantly increases the rates of environmental disturbance, being one of the main causes of habitat loss and biodiversity. The growing trend of converting the natural landscape into areas for real estate speculation in the coastal region of the southernmost part of Brazil is a current concern, as the region is home to unique ecosystems, such as dunes, wetlands and large brackish lagoons. As they are organisms sensitive to environmental changes, variations in the structure of Odonata communities are used as indicators of habitat quality reflecting the human impact on the environment. Here we assessed how the Odonata community is affected by the growing urbanization around natural ponds on the coast of the state of Rio Grande do Sul, testing the hypothesis that the increase in the percentage of urbanization negatively influences the Odonata community, following the same pattern found for other groups of invertebrates. The collections took place in 28 coastal ponds, which were classified as urbanized and non-urbanized based on the surrounding ground cover. Anisoptera's richness, abundance and composition were influenced by urbanization, but the same was not found for Zygoptera. The analysis of indicator species specifies three species associated with non-urbanized areas: Erythrodiplax sp.1, Erythemis credula and Telebasis corallina. Our study highlights the importance of Odonata as organisms that indicate environmental integrity and reinforces the need for urban planning strategies that favor the conservation and maintenance of the environments affected by urbanization.
\end{abstract}

Keywords: Anisoptera; aquatic conservation; aquatic insects; urban ecology; ponds; Zygoptera.

\section{Efeitos da urbanização sobre a fauna de Odonata no litoral sul do Brasil}

Resumo: A urbanização aumenta significativamente as taxas de perturbação ambiental, sendo está uma das principais causas da perda de habitat e biodiversidade. A tendência crescente de conversão da paisagem natural em áreas para especulação imobiliária na região costeira do extremo sul do Brasil é uma preocupação atual, pois a região abriga ecossistemas únicos, como dunas, áreas úmidas e grandes lagoas salobras. Como são organismos sensíveis às alterações ambientais, as variações na estrutura das comunidades de Odonata são utilizadas como indicadores de qualidade do habitat refletindo o impacto humano no ambiente. Nós avaliamos como a comunidade de Odonata é afetada pela crescente urbanização em torno de lagoas naturais no litoral do estado do Rio Grande do Sul, testando a hipótese de que o aumento do percentual de urbanização influencia negativamente a comunidade de Odonata, seguindo o mesmo padrão encontrado para outros grupos de invertebrados. As coletas ocorreram em 28 lagoas costeiras, que foram classificadas como urbanizadas e não urbanizadas com base na cobertura do solo no entorno. A riqueza, abundância e composição de Anisoptera foram influenciadas pela urbanização, mas o mesmo não foi encontrado para Zygoptera. A análise de espécies indicadoras especifica três espécies associadas a áreas não urbanizadas: Erythrodiplax sp.1, Erythemis credula e Telebasis corallina. Nosso estudo destaca a importância dos Odonata como organismos indicadores de integridade ambiental e reforça a necessidade de estratégias de planejamento urbano que favoreçam a conservação e manutenção dos ambientes afetados pela urbanização.

Palavras-chave: Anisoptera; conservação aquática; insetos aquáticos; ecologia urbana; lagoas; Zygoptera. 


\section{Introduction}

Urban areas are cultural spaces with a high density of people. They have extensive impermeable surfaces that are occupied by infrastructure, forming a dynamic mosaic. In this context, the process of landscape change for the establishment of urban areas is called urbanization (Muzón et al. 2019). Urbanization has significantly increased the rates of environmental disturbance, this being one of the main causes of habitat and biodiversity loss (Czech et al. 2000, McDonald et al. 2008). The construction of buildings and roads leads to great changes in the natural landscapes, destroying and homogenizing habitats. Urbanization is the cause of some of the greatest local extinctions (McKinney 2002), reducing species richness and abundance of certain taxa (McKinney 2008, Buczkowski \& Richmond 2012). However, the urban environment might harbor some endangered species and can also promote the diversity of some species adapted to the conditions imposed by urbanization as it reduces the richness of native species (McKinney \& Lockwood 1999).

In southern Brazil, the coastal region follows a national tendency of the urbanization, where there is a valuing coastal area, mainly because of political and economic reasons (Moraes 2007). Urban development on the coast began in the 1980s and became more intense as acquiring properties became easier (Strohaecker 2007). The coastal zone of Rio Grande do Sul harbors rare ecosystems, such as wetlands and brackish lagoons, which are ecosystems with great environmental vulnerability (Strohaecker 2007). In the face of the extension of the impacts caused by urban development, it becomes increasingly essential to understand the effects of urbanization on natural habitats.

According to Muzón et al. (2019), almost all known orders of aquatic insects can inhabit freshwater ecosystems in urban areas. However, urbanization is a complex process. Several studies describe the effects of urbanization on richness and abundance of different groups such as birds (Chace \& Walsh 2006), mammals (Tait et al. 2005), reptiles (Barret \& Guyer 2008), amphibians (Hamer \& McDonnell 2008) and several groups of land arthropods (McIntyre et al. 2001), showing that the effects of urbanization can vary according to taxon. However, most studies show a negative effect associated with urbanization, which can be explained mostly by habitat loss and/or degradation of the remaining habitat (McKinney 2008).

One of the most representative orders of aquatic insects is Odonata. These insects are found in a variety of water bodies, from rivers and streams to lakes and temporary ponds (Corbet 1999), being frequently mentioned as indicators of habitat quality because, through variations in their community structure, they can reflect the human impact on the environment (Clark \& Samways 1996, Callisto et al. 2001, FerreiraPeruquetti \& De Marco 2002, Oliveira-Junior et al. 2015, Renner et al. 2016, Renner et al. 2018, Renner et al. 2019).

Odonata are among the best-known insect groups in the world (Kalkman et al. 2008). Odonata are estimated to comprise 6322 species in the world (Schorr \& Paulson 2019), and the Neotropical region harbors the second highest diversity, with more than 1700 species (Von Ellenrieder 2009). About 750 species are known to occur in Brazil (Olaya 2019), and, in the state of Rio Grande do Sul, a survey indicated the presence of 182 species (Dalzochio et al. 2018a).

Some studies aimed to evaluate the effect of urbanization on the Odonata community. They suggest that the changes occurring in the process, both in the landscape scale (Samways \& Steytler 1996) and the physical and chemical parameters of water (Corbet 1999), may negatively affect the diversity pattern of this order. However, the impact is different depending on the species (Monteiro-Júnior et al. 2014). Zygoptera species, in general, are more sensitive to environmental disturbances, as they have narrower niches and less dispersion capacity, when compared to anisopterans (Monteiro-Júnior et al. 2015, Corbet 1999). Thus, some species of Zygoptera may be less tolerant to urban lentic environments, consequently presenting less diversity (Prescott \& Eason 2018). In contrast, Anisoptera species are favored in this type of environment, since they are more generalist and have greater dispersion capacity (Corbet 1999, Goertzen \& Suhling 2013). The two suborders also have different thermoregulatory requirements, and in open landscapes, such as wetlands, there is a predominance of Anisoptera species (Juen et al. 2014).

In this context, our work seeks to answer the following questions: 1) How does percent urbanization affects species richness, abundance and composition in the coastal plain of Rio Grande do Sul? 2) Are there species that can be considered indicators of urbanized or non-urbanized environments?

We expected that the increase in percent urbanization will have a negative influence on the Odonata community in this region, following the same pattern found for several invertebrate groups. However, some species may be more tolerant of this variable.

\section{Material and Methods}

\section{Study area}

The study was conducted in natural ponds in the municipalities of the coastal plain of the state of Rio Grande do Sul. The state of Rio Grande do Sul is located in the southern portion of Brazil $\left(27^{\circ} 04^{\prime}-33^{\circ} 45^{\prime}\right.$ $\mathrm{S} ; 4^{\circ} 42^{\prime}-57^{\circ} 38^{\prime} \mathrm{W}$ ) (Figure 1) with an area of about $282.000 \mathrm{~km}^{2}$. The coastal plain is characterized by a sedimentary plain consisting of dunes, ponds and lagoons (Strohaecker 2007). According to the delimitation established by the Program of Coastal Management (GERCO-RS) of the State Program of Environmental Protection (FEPAM), the northern coast has an extension of $120 \mathrm{~km}$ of coastal line and a surface area of $3700 \mathrm{~km}^{2}$. The dominant climate is subtropical, belonging, according to Köppen's classification, to the Cfa type (Kuinchtner \& Buriol 2001), having well-defined four seasons with a mean temperature of $15^{\circ} \mathrm{C}$ in winter and $27^{\circ} \mathrm{C}$ in summer. The terrain has a mean altitude of 40 and 50 meters and the annual precipitation varies between 1500 and 1700 $\mathrm{mm}$ (Rossato 2011).

\section{Sample design}

We sampled 28 ponds, respecting a minimum distance of $1000 \mathrm{~m}$ between them. In this context, we delimited a radius of $1 \mathrm{~km}$ from the center of the sampling pond and, using the tool ruler to calculate area and the most recent images available in the software Google Earth Pro $^{\mathrm{TM}}$, we calculated the percentage of the areas with built structures, such as roads, houses and buildings. Thus, the study included 15 nonurbanized ponds and 13 urbanized. Ponds with urbanization percentage points below $20 \%$ were considered non-urbanized and those with more than $20 \%$ of urbanization were considered urbanized. The area of the sampled pond varied from 0.0027 to 3.96 hectares (Figure 1). The ponds were sampled twice between November 2016 and March 2018, 


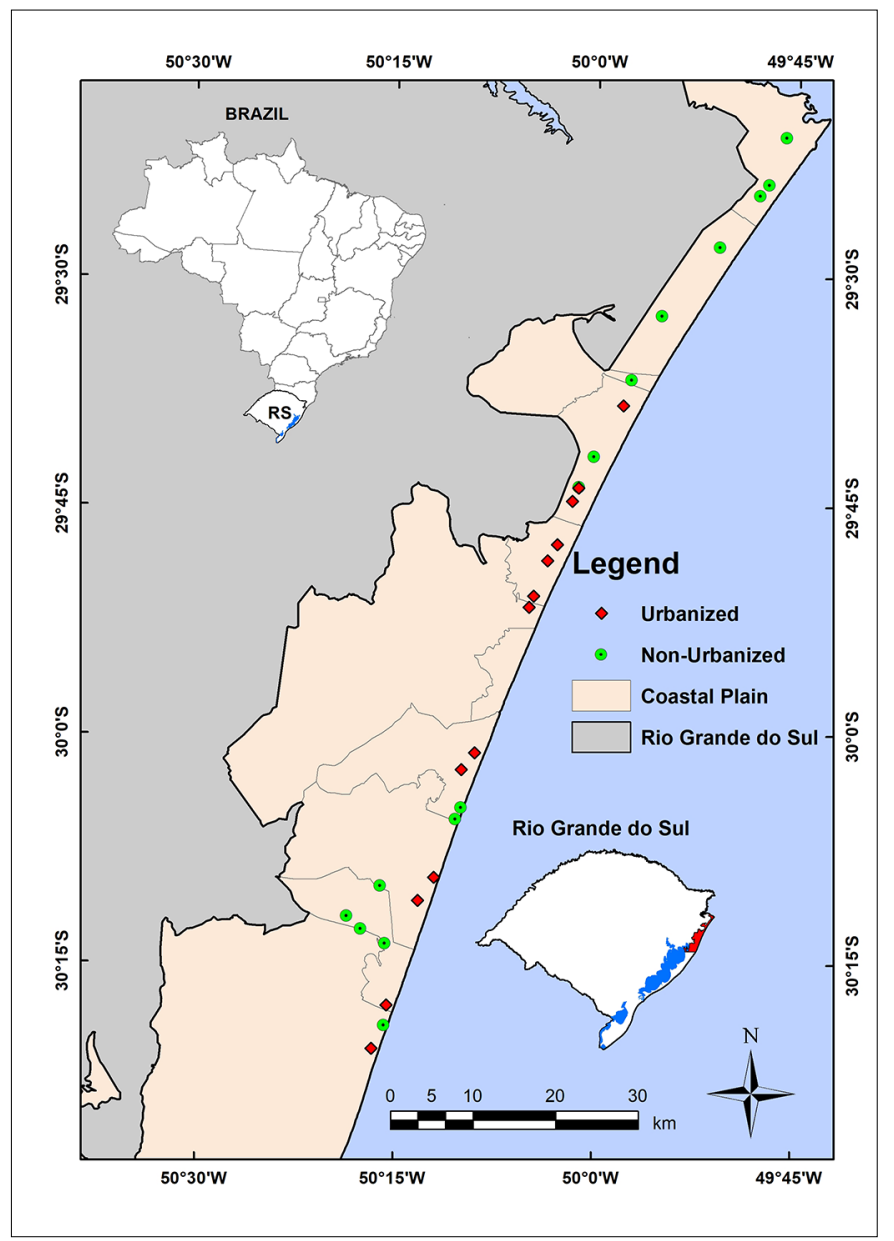

Figure 1. Location of the sampled areas on the northern coast of the state of Rio Grande do Sul.

except in winter due to the absence of activity of Odonata adults, the two samples per pond were added.

\section{Collection of biological material}

The study was based on the collection of adults. Specimens were collected using aerial insect nets by a team consisting of three researchers and a sampling effort of 40 minutes per locality. Collections were performed solely on sunny days, between 10:00 and 16:00 hours. Captured specimens were immediately fixed in 96\% ethanol and preserved in glass flasks that were identified with collection date and location for later determination in the laboratory.

Species determination was conducted in the Laboratory of Ecology and Evolution of UNIVATES with the aid of a stereomicroscope and identification keys for Odonata adults of the Neotropical region: Garrison et al. (2006); Garrison et al. (2010), Heckman (2008), Heckman (2006), Lencioni (2005) and Lencioni (2006). The specimens will be housed in the invertebrate collection of the Natural History Museum of UNIVATES (MCNU).

\section{Data analysis}

Species (S) richness was considered as the number of species, while abundance was considered as the total number of individuals. The analyses were conducted separately for each suborder of Odonata, as they are biologically and ecologically distinct (Dutra \& De Marco
2015). All statistics routines were conducted in the statistical program $\mathrm{R}$ project (R Core Team 2019).

Due to the possibility of containing a greater number of perches in the non-urbanized area, since its surrounding vegetation is preserved, we have developed a coverage-based rarefaction analysis, according to Chao et al. (2014). We used package rareNMtests and rarefaction. individual function (Cayuela \& Gotelli 2014).

To determine the relation of urbanization to richness and abundance for each suborder, we elaborated a Generalized Linear Mixed Model (GLMM). We used the percentage of urbanization of each sampled site as an explanatory variable and as a random variable the log area $\left(\mathrm{m}^{2}\right)$ of the ponds. These analyses were conducted using the package lme4 (Bates et al. 2015) and the function glmer. For both suborders, richness followed a negative binomial distribution and abundance followed a Poisson distribution.

To evaluate whether urbanized and non-urbanized ponds were similar regarding species composition, we used the abundance data matrix transformed into Hellinger. First, we conducted a dispersion analysis (PERMDISP), to understand how homogeneous the samples were within the treatments, using the betadisper function. Next, we conducted an One-Way Permanova using Bray-Curtis dissimilarity index and 9999 permutations, with the adonis2 function. To represent the results found at Permanova, an NMDS was created, using the vegan package and the metaMDS function. Both functions are from the Vegan package (Oksanen et al. 2019).

With the purpose of knowing which species could serve as indicators in environments with and without urbanization influence, we obtained information through the analysis of indicator species (INDVAL - Dufrene \& Legendre 1997). This index is calculated estimating the specificity (whether the species shows an association with certain habitat types, occurring only in certain environments or conditions) and fidelity (whether the species is invariably present under a certain environmental condition). This analysis was elaborated with the aid of the package labdsv 1.5.0 for R project (Roberts 2012). To complement the INDVAL analysis, we applied the Multinomial Species Classification Method (Chazdon et al. 2011), which uses a multinomial model based on estimated species relative abundance to classify species as generalists and specialists in two distinct habitats, with the package vegan, function clamtest.

\section{Results}

The areas of the analyzed ponds ranging from $26 \mathrm{~m}^{2}$ to $39,79 \mathrm{~m}^{2}$, with an average of $3,47 \mathrm{~m}^{2}$. The richness varied from $3 \mathrm{spp}$ to $13 \mathrm{spp}$, with an average of $8 \mathrm{spp}$. The abundance ranged from 9 individuals to 55 individuals, with an average of 29 individuals (Table 1). A total of 820 individuals were collected, in 38 species and 17 genera, with Orthemis schmidti Buchholz, 1950 being a new record for the state. Anisoptera was the most abundant suborder with 462 individuals belonging to 11 genera and two families, Libellulidae and Gomphidae. Zygoptera had 358 individuals distributed into 6 genera and two families, Coenagrionidae and Lestidae (Table 2).

The most abundant species of Anisoptera were Erythrodiplax paraguayensis (Förster, 1904) $(\mathrm{n}=124)$ and Erythrodiplax sp.1(n = 102), which represented $49 \%$ of the total number of individuals of this suborder that were collected in this study. The most abundant 
Sganzerla, C. et al.

Table 1. Sampling locations: coordinates, pond area, percentage of urbanization, classification of the environment, richness e abundance.

\begin{tabular}{|c|c|c|c|c|c|c|}
\hline Sites & Coordinate & Pond $\left(\mathrm{m}^{2}\right)$ & Urbanization (\%) & Environment & Richness & Abundance \\
\hline 1 & S 2951'42.1" W 5004'59.8" & 1031 & 51 & Urbanized & 5 & 25 \\
\hline 2 & S $29^{\circ} 50^{\prime} 57.3^{\prime \prime} \mathrm{W} 50^{\circ} 04^{\prime} 40.8^{\prime \prime}$ & 490.37 & 40 & Urbanized & 3 & 10 \\
\hline 4 & S $29^{\circ} 47^{\prime} 34.1^{\prime \prime} \mathrm{W} 50^{\circ} 02^{\prime} 55.5^{\prime \prime}$ & 173.69 & 40 & Urbanized & 9 & 23 \\
\hline 5 & S $29^{\circ} 44^{\prime} 44.1^{\prime \prime}$ W $50^{\circ} 01^{\prime} 48.51^{\prime \prime}$ & 191.85 & 55 & Urbanized & 9 & 15 \\
\hline 8 & S 29॰43'50.9" W 5001'20.5" & 6077.6 & 31 & Urbanized & 8 & 31 \\
\hline 9 & S $30^{\circ} 01^{\prime} 16^{\prime \prime} \mathrm{W} 50^{\circ} 09^{\prime} 01^{\prime \prime}$ & 113.26 & 98 & Urbanized & 5 & 25 \\
\hline 10 & $\mathrm{~S} 30^{\circ} 10^{\prime} 57^{\prime \prime} \mathrm{W} 50^{\circ} 13^{\prime} 14^{\prime \prime}$ & 1478.92 & 37 & Urbanized & 9 & 36 \\
\hline 11 & S $30^{\circ} 09^{\prime} 26^{\prime \prime} \mathrm{W} 50^{\circ} 12^{\prime} 03^{\prime \prime}$ & 1249.13 & 46 & Urbanized & 8 & 55 \\
\hline 15 & S 29³6'45.5" W 4957'25.3" & 2597.74 & 3 & Non-urbanized & 7 & 30 \\
\hline 16 & S $29^{\circ} 41^{\prime} 48.2^{\prime \prime}$ W 5000'13.3" & 4254.79 & 14 & Non-urbanized & 12 & 55 \\
\hline 17 & S 29³2'32.7" W 4955'10.6" & 2973.77 & 4 & Non-urbanized & 9 & 34 \\
\hline 18 & S $29^{\circ} 28^{\prime} 00.5^{\prime \prime} \mathrm{W} 49^{\circ} 50^{\prime} 52.8^{\prime \prime}$ & 3883.59 & 6 & Non-urbanized & 9 & 43 \\
\hline 19 & S 29²4'37.5" W 4947'55.5" & 10258.92 & 7 & Non-urbanized & 5 & 28 \\
\hline 20 & S 29²3'53.9" W 4947'14.3" & 2258.8 & 16 & Non-urbanized & 8 & 24 \\
\hline 21 & S 29²0'48.3" W 49²5'57.8" & 1367.8 & 17 & Non-urbanized & 7 & 15 \\
\hline 22 & S 2943'47.6" W 5001'19.4" & 816.97 & 20 & Non-urbanized & 7 & 21 \\
\hline 23 & S $30^{\circ} 05^{\prime} 37^{\prime \prime} \mathrm{W} 50^{\circ} 10^{\prime} 26^{\prime \prime}$ & 2006.09 & 2 & Non-urbanized & 9 & 27 \\
\hline
\end{tabular}

species of Zygoptera were Ischnura fluviatilis Selys, $1876(\mathrm{n}=217)$ and I. capreolus (Hagen, 1861) $(\mathrm{n}=89)$, which made up $85 \%$ of the specimens in this suborder.

The coverage-based rarefaction analysis indicates the same percentage of coverage for both urbanized and non-urbanized areas (Figure 2). Although the coverage sample value was lower than 0,6 , this curve indicates that there is no bias caused by possible higher numbers of perches in non-urbanized areas.

The mean richness of Anisoptera per point was 5.16 species, while that of Zygoptera was 2.60. The GLMM showed that urbanization does not influence the richness of Anisoptera $(Z=-1.32$; $p=0.187$ neither Zygoptera $(Z=-0.071 ; p=0.943)$. The mean abundance of Anisoptera per point was 16.5 individuals, while that of Zygoptera was 12.78. The GLMM showed that urbanization has a negative influence on the abundance of Anisoptera $(Z=-2.82 ; p=0.004)$ (Figure 3$)$ but does not influence the abundance of Zygoptera $(Z=-0.251 ; p=0.802)$.

The dispersion analysis (PERMDISP) did not indicate heterogeneity in the samples of Zygoptera $(\mathrm{F}=0.152 ; \mathrm{p}=0.699)$ or Anisoptera $(\mathrm{F}=$ $2.65 ; \mathrm{p}=0.115)$. The PerMANOVA, indicated significant differences in
Anisoptera species composition between urbanized and non-urbanized environments $\left(\mathrm{F}_{1 ; 27}=3.235 ; \mathrm{p}=0.001\right)$, while the composition of Zygoptera was not statistically different between the studied environments $\left(\mathrm{F}_{1 ; 27}=0.3774 ; \mathrm{p}=0.821\right)$ (Figure 4).

The indicator species analysis (INDVAL) indicated only three species associated with non-urbanized areas: Erythrodiplax sp.1 $($ INDVAL $=0.861 ; \mathrm{p}=0.005)$, Erythemis credula (Hagen, 1861) (INDVAL $=0.789 ; \mathrm{p}=0.005)$ and Telebasis corallina (Selys, 1876) (INDVAL $=0.632 ; \mathrm{p}=0.025$ ). These three species were classified as "non-specialists" for non-urbanized areas by the Multinomial Species Classification Method. Although without significant values, the species Brachymesia furcata (Hagen, 1861), Erythrodiplax fusca (Rambur, 1842), Erythrodiplax latimaculata Ris, 1911, Erythrodiplax umbrata (Linnaeus, 1758), Lestes paulistus Calvert, 1909, Libellula herculea Karsch, 1889, Micrathyria stawiarskii Santos, 1953, Orthemis schmidti Buchholz, 1950, Progomphus intricatus Hagen in Selys, 1858, Tramea abdominalis (Rambur, 1842) and Tramea cophysa Hagen, 1867 were found exclusively in non-urbanized areas, while Acanthagrion gracile (Rambur, 1842), Acanthagrion lancea Selys, 1876, Erythemis attala 
Effects of urbanization on the fauna of Odonata

Table 2. Species collected in the study sites on the northern coast of Rio Grande do Sul, Brazil, between November 2016 and March 2018

\begin{tabular}{|c|c|c|c|}
\hline Species and families & Urbanized & Non-urbanized & Total \\
\hline \multicolumn{4}{|l|}{ Gomphidae } \\
\hline Progomphus intricatus Hagen, 1858 & 0 & 1 & 1 \\
\hline Brachymesia furcata (Hagen, 1861) & 0 & 1 & 1 \\
\hline Erythrodiplax sp.1 & 13 & 89 & 102 \\
\hline Erythemis attala (Selys, 1857) & 1 & 0 & 1 \\
\hline Erythemis credula (Hagen, 1861) & 4 & 26 & 30 \\
\hline Erythemis peruviana (Rambur, 1842) & 2 & 9 & 11 \\
\hline Erythrodiplax atroterminata Ris, 1911 & 15 & 7 & 22 \\
\hline Erythrodiplax fusca (Calvert,1895) & 0 & 1 & 1 \\
\hline Erythrodiplax nigricans (Rambur, 1842) & 2 & 0 & 2 \\
\hline Erythrodiplax paraguayensis (Förster, 1905) & 41 & 83 & 124 \\
\hline Erythrodiplax umbrata (Linnaeus, 1758) & 0 & 1 & 1 \\
\hline Libellula herculea (Selys, 1857) & 0 & 1 & 1 \\
\hline Micrathyria catenata Calvert, 1909 & 2 & 0 & 2 \\
\hline Micrathyria spuria (Selys, 1900) & 2 & 1 & 3 \\
\hline Micrathyria stawiarskii Santos, 1953 & 0 & 2 & 2 \\
\hline Nephepeltia flavifrons (Karsch, 1889) & 12 & 5 & 17 \\
\hline Tramea binotata (Rambur, 1842) & 1 & 0 & 1 \\
\hline Tramea cophysa Hagen, 1867 & 0 & 2 & 2 \\
\hline \multicolumn{4}{|l|}{ Coenagrionidae } \\
\hline Acanthagrion gracile (Rambur, 1842) & 1 & 0 & 1 \\
\hline Acanthagrion lancea Selys, 1876 & 3 & 0 & 3 \\
\hline Argia sp. & 0 & 2 & 2 \\
\hline Homeoura chelifera (Selys, 1876) & 13 & 10 & 23 \\
\hline Ischnura capreolus (Hagen, 1861) & 44 & 45 & 89 \\
\hline Ischnura fluviatilis (Selys, 1876) & 103 & 114 & 217 \\
\hline Telebasis corallina & 0 & 17 & 17 \\
\hline Telebasis willinkii Fraser, 1948 & 2 & 2 & 4 \\
\hline \multicolumn{4}{|l|}{ Lestidae } \\
\hline Lestes paulistus Calvert, 1909 & 0 & 1 & 1 \\
\hline Lestes undulatus Say, 1840 & 1 & 0 & 1 \\
\hline Total & 326 & 494 & 820 \\
\hline
\end{tabular}

* First record for the State of Rio Grande do Sul 
Sganzerla, C. et al.

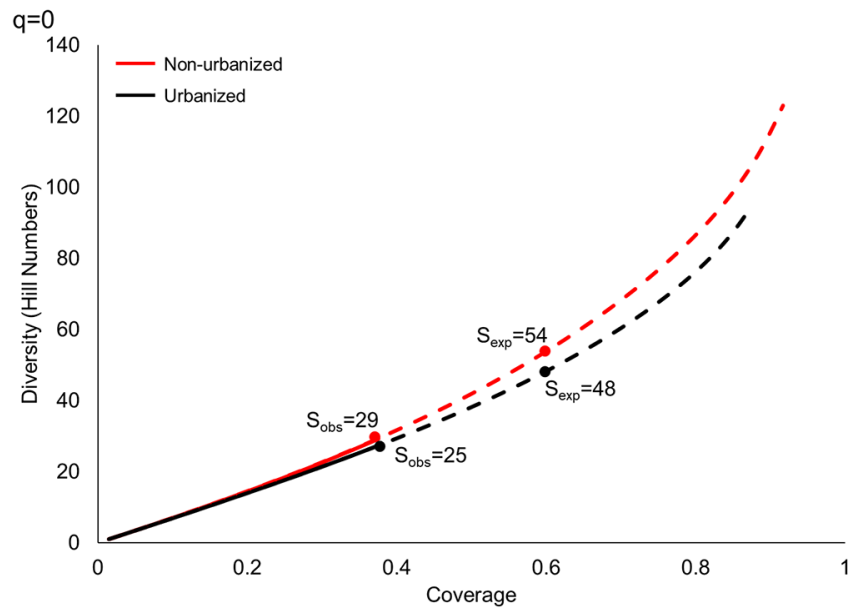

Figure 2. Coverage-based rarefaction analysis (urbanized and non-urbanized area).

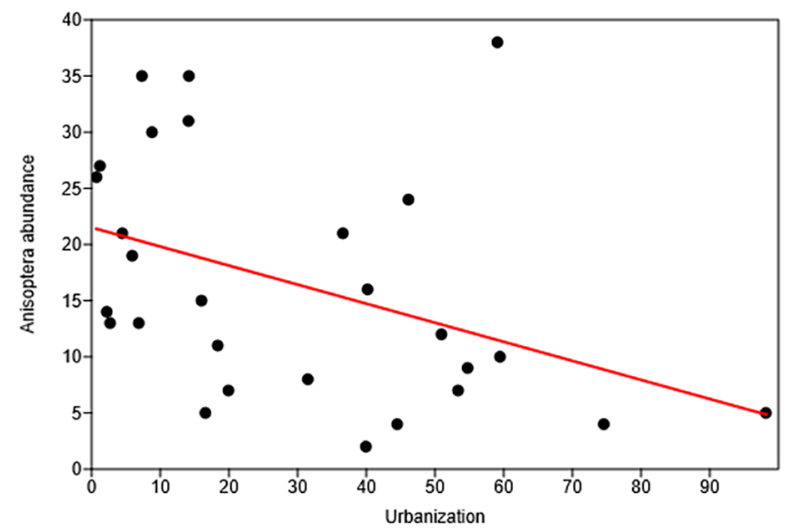

Figure 3. Generalized linear model (GLMM) for abundance Anisoptera.
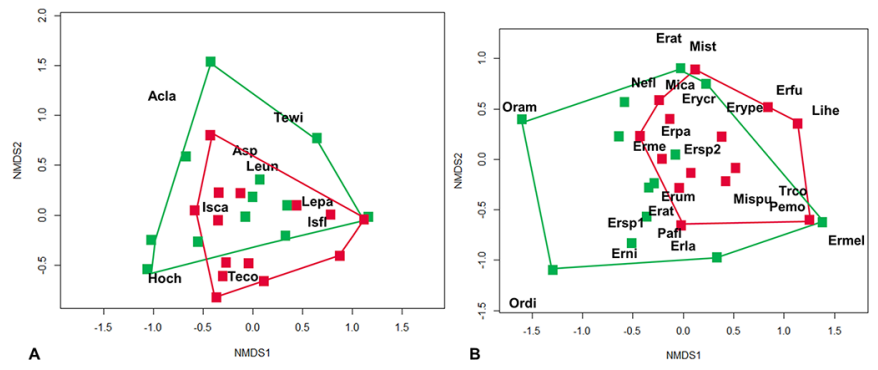

Figure 4. NMDS representing the composition of Zygoptera (A) and Anisoptera (B) species in urbanized (green) and non-urbanized (red) ponds.

(Selys, 1857), Erythrodiplax melanoruba Borror, 1942, Erythrodiplax nigricans (Rambur, 1842), Lestes undulatus Say, 1840, Micrathyria catenata Calvert, 1909, Orthemis discolor (Burmeister, 1839) and Tramea binotata (Rambur, 1842). were found exclusively in urbanized areas (Table 3).

\section{Discussion}

The expansion of urban areas and the consequent loss and fragmentation of habitats, is one of the most significant environmental impacts on natural landscapes (Villalobos-Jiménez et al. 2016). Despite the importance of studies that assess the impact of urbanization on aquatic habitats, there are few studies on the use of ponds by species of aquatic insects, regarding they use to environmental integrity (Willigalla \& Fartmann 2012). Adequate pond management can be an important factor in conservation strategies (Chien et al. 2019), and ponds, even small and in urban areas, can work as a reservoir for several species, as well as present similar species richness and aquatic invertebrate families when compared to non-urban ponds, although there are clear differences in the composition of communities (Hill et al. 2016).

Species of the order Odonata are excellent indicators of environmental quality, and species composition, followed by diversity and taxonomic distinctness, are the parameters that best respond to environmental disturbance gradients (Miguel et al. 2017). In general, studies with Odonata that consider urbanization gradients demonstrate that species richness increases along a gradient from the center of a city to the rural area and is significantly highest in rural areas (Willigalla \& Fartmann 2012). Studies in the Cerrado biome, in open areas, indicate that zygopteran species richness decreased as habitat integrity decreased, with the opposite pattern being observed for the anisopterans (Carvalho et al. 2013).

Our results showed that urbanization is a predictor variable for the structuring of the Odonata community on the coast of Rio Grande do Sul, influencing abundance, richness and composition of the suborder Anisoptera. Species of Zygoptera seem to be influenced by other factors since the variable urbanization had no significance for the analyzed metrics.

This is the first study that characterized the Odonata fauna on the coastal area of Rio Grande do Sul. The 38 species found correspond to $21 \%$ of the total known for this state (Dalzochio et al. 2018a). The most species were lentic species typical of wetland environments, which are characteristic of the sampled region. The model explained that the richness and abundance of Anisoptera were negatively influenced by the urbanized areas, but there was no variation in richness and abundance of Zygoptera. Most likely these results are related to the ecological needs of these suborders. In this context, species of Zygoptera have a higher ecological diversity and some species can be considered eurytopic (Samways \& Steytler 1996). Therefore, they are not subject to significant changes in their richness and abundance in urbanized ecosystems. However, specialist species can also find refuge in urbanized areas (Harabiš \& Dolný 2015). As analyzed by Monteiro-Junior et al. (2014), habitats heavily degraded by urbanization lead to a loss in the number of species of both suborders.

The landscape around the sampled areas (e. g. buildings and paved roads) is a predictor variable for the species richness and abundance patterns (Jeanmougin 2014) since the landscape surrounding the aquatic environments is fundamental for the foraging and maturation of Odonata species (Bried \& Ervin 2006). Generally, the increase in urbanization has a negative effect on the diversity of these animals. However, there are more generalist species that are able to live in human-disturbed habitats (Clark \& Samways 1996). 
Effects of urbanization on the fauna of Odonata

Table 3. Indicator species (INDVAL) and their respective classification by Multinomial Species Classification Method (CLAM). Values in bold are statistically significant for INDVAL.

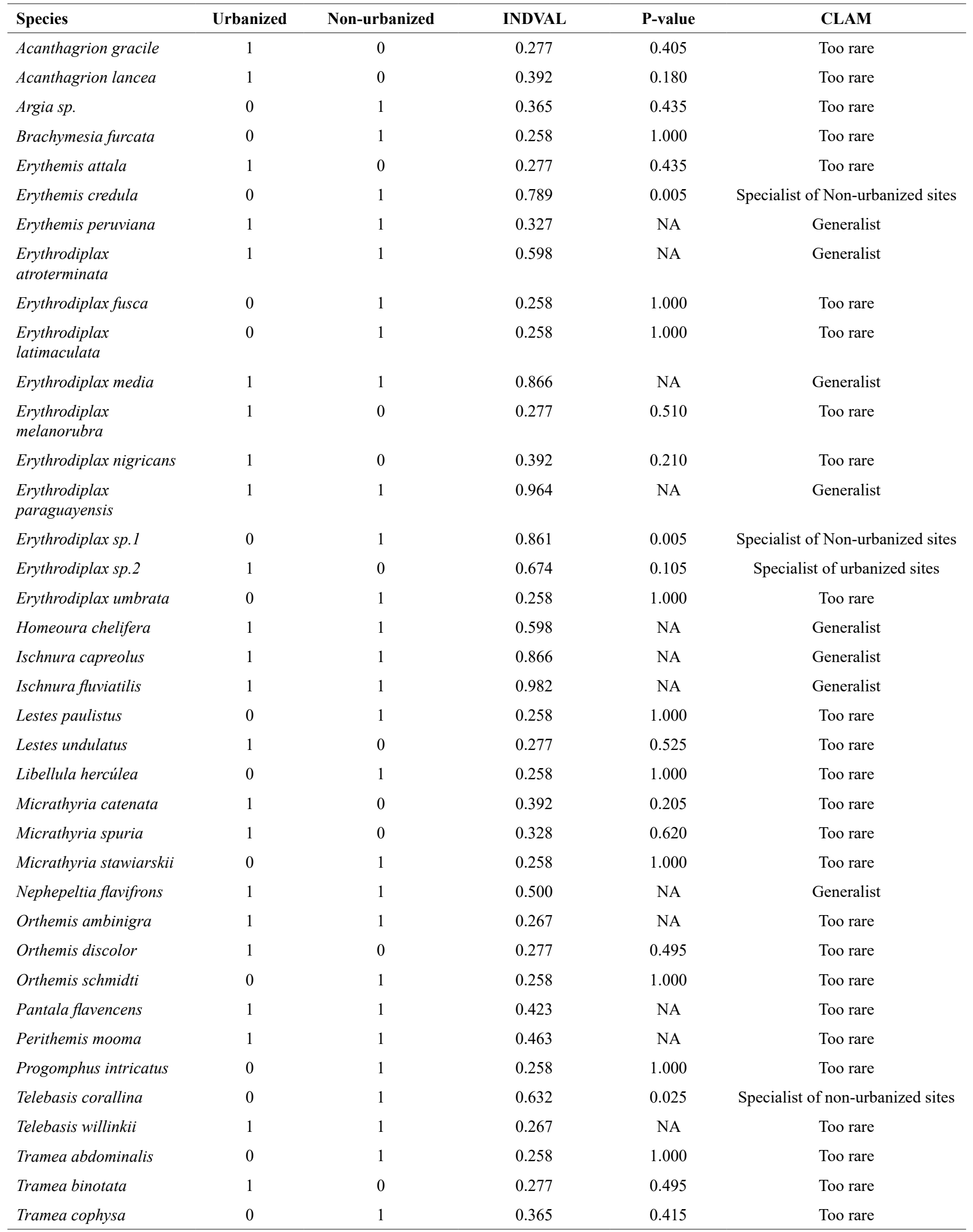


The changes in land use and land cover from the urbanization process in the region are recent, beginning in the 1990s (1995), and correspond to the fourth cycle of occupation of the northern coast of Rio Grande do Sul (Lopes et al. 2018). Therefore, it is likely that it is not yet possible to measure the process of adaptation of Odonata species (Goertzen \& Suhling 2019). Additionally, the urbanization process in the tropics usually occurs rapidly, causing the loss of sensitive species (Monteiro-Júnior et al. 2014).

Regarding species composition, although Zygoptera was not influenced by urbanization, all landscape elements act in biological communities, which, in turn, interact to structure the whole environment (Turner \& Gardner 2001). The dimension and number of certain landscape elements are crucial for the formation and continuity of specific communities (Bond \& Parr 2010). In addition, target taxa, such as Odonata, respond to anthropogenic changes. Therefore, the species distribution and general diversity of these taxa are related to the landscape structure or to the variables of land use (Soares Filho 1998). The variable urbanization, in this case, may have limited the dispersion of certain species of Anisoptera, while not affecting other species, such as Zygoptera.

Studies in lagoons in North America and Europe found that the richness of Odonata increases or is not affected by urban processes (Craves \& O'Brien 2013, Goertzen \& Suhling 2013), which indicates that some species are likely becoming tolerant to urbanization. This can be the case of species found in urbanized environments: Acanthagrion gracile, Acanthagrion lancea, Erythemis attala, Erythrodiplax melanorubra, Erythrodiplax nigricans, Lestes undulatus, Micrathyria catenata, Orthemis discolor and Tramea binotata. Most species belonging to the genera Acanthagrion, Erythemis, Erythrodiplax, Lestes, Micrathyria and Orthemis are considered generalists (Dalzochio et al. 2018b). They have short life cycles and adapt very quickly to environmental changes, being found even in very hostile environments. Moreover, generalist species can explore the available resources due to reduced competition, resulting in the high abundance of tolerant species (Villalobos-Jiménez et al. 2016).

In this regard, one of the species that was pointed out as an indicator of non-urbanized environments, Erythrodiplax sp.1, was unexpected since most species in this genus are considered generalists (Dalzochio et al. 2018b). However, there are cases in which species of the genus Erythrodiplax were established as bioindicators, for example, in the Cerrado biome, were the genus indicated pasture environments and non-shaded areas (Dutra \& De Marco 2015). The suggestion of the species Telebasis corallina and Erythemis credula as bioindicators may be associated with the presence of macrophytes or with the physical and chemical parameters of the sampled locations (Fulan et al. 2011). In this context, species of Zygoptera, such as Telebasis corallina, are more vulnerable to changes in landscape structure and vegetation cover and may become locally extinct (Monteiro-Júnior et al. 2015).

We observed that the richness and abundance of the species of the suborder Anisoptera was reduced with urban expansion through the construction of buildings, pavement of roads and high flow of people. In this sense, urban planning is necessary to ensure ecosystem maintenance and limit environmental degradation. However, due to the complexity of the human occupation in this region, more studies are necessary. Additionally, we suggest the use of Odonata to evaluate these environments. We hope that this study will help with measurements that aim to restore, conserve and maintain environments affected by urbanization.

\section{Acknowledgments}

We thank our colleagues of the sector of Ecology and Evolution: Samuel Renner for his help in identifying specimens, and Gerson Luiz Ely Júnior and Tiago da Silva for their help in the field and in identifying specimens. Rafael Eckhardt kindly help with study area map. We also thank FAPERGS and UNIVATES for research grants, CAPES (Process no. 88887.125260/2015-00; PVE 95/2015) and CNPq (Process no.307303/2019-5) for funding this study.

\section{Author Contributions}

Cléber Sganzerla: Contribution to data collection, data analysis and interpretation and manuscript preparation.

Marina Schmidt Dalzochio: Contribution to data collection, data analysis and interpretation and manuscript preparation.

Gabriel dos Santos Prass: Contribution to data collection and manuscript preparation.

Eduardo Périco: Contribution in the concept and design of the study, data analysis and interpretation and manuscript preparation.

\section{Conflicts of interest}

The authors declare that they have no conflict of interest related to the publication of this manuscript.

\section{References}

BARRETT, K. \& GUYER, C. 2008. Differential responses of amphibians and reptiles in riparian and stream habitats to land use disturbances in western Georgia, USA. Biol. Conserv. 141(9):2290-2300.

BATES, D., MÄCHLER, M., BOLKER, B. \& WALKER, S. 2015. Fitting Linear Mixed-Effects Models Using lme4. J. Stat. Softw. 67(1):1-48.

BOND, W. J. \& PARR, C. L. 2010. Beyond the forest edge: ecology, diversity and conservation of the grassy biomes. Biol. Conserv. 143(10):2395-2404.

BRIED, J. T. \& ERVIN, G. N. 2006. Abundance patterns of dragonflies along a wetland buffer. Wetlands 26(3):878-883.

BUCZKOWSKI, G. \& RICHMOND D. S. 2012. The effect of urbanization on ant abundance and diversity: a temporal examination of factors affecting biodiversity. PloS one 7(8):e41729.

CALLISTO, M., MORETTI M. \& GOULART, M. 2001. Macroinvertebrados bentônicos como ferramenta para avaliar a saúde de riachos. RBRH 6(1):71-82.

CARVALHO, F. G., PINTO, N. S., OLIVEIRA-JUNIOR. J. S. B. \& JUEN, L. 2013. Effects of marginal vegetation removal on Odonata communities. Acta Limnol. Bras. 25(1):10-18.

CHACE, J. F. \& WALSH, J. J. 2006. Urban effects on native avifauna: a review. Landscape urban plan. 74(1):46-69.

CHAO, A., GOTELLI, N. J., HSIEH, T. C., SANDER, E. L., MA, K. H., COLWELL, R. K. \& ELLISON, A. M. 2014. Rarefaction and extrapolation with Hill numbers: a framework for sampling and estimation in species diversity studies. Ecol. Monogr. 84(1):45-67.

CHAZDON, R. L., CHAO, A., COLWELL, R. K., LIN, S.Y., NORDEN, N., LETCHER, S. G., CLARK, D. B., FINEGAN, B. \& ARROYO, J. P. 2011. A novel statistical method for classifying habitat generalists and specialists. Ecology 92(6):1332-1343.

CHIEN, W. C., LI, M. H. \& LI, H. J. 2019. Appropriate management practices help enhance odonate species richness of small ponds in peri-urban landscapes. Urban Ecosyst. 22(4):757-768.

CLARK, T. E. \& SAMWAYS, M. J. 1996. Dragonflies (Odonata) as indicators of biotope quality in the Kruger National Park, South Africa. J. Appl. Ecol. 33(5):1001-1012.

CORBET, P. S. 1999. Dragonflies - Behaviour and Ecology of Odonata. Harley Books, Colchester. 
CRAVES, J. A. \& O'BRIEN, D. S. 2013. The Odonata of Wayne County, MI: inspiration for renewed monitoring of urban areas. Northeast. Nat. 20(2):341-362.

CZECH, B., KRAUSMAN P. R. \& DEVERS, P. K. 2000. Economic associations among causes of species endangerment in the United States. BioScience 50(7):593-601.

DALZOCHIO, M. S., PÉRICO, E., RENNER, S. \& SAHLÉN, G. 2018b. Effect of tree plantations on the functional composition of Odonata species in the highlands of southern Brazil. Hydrobiologia 808(1):283-300.

DALZOCHIO, M. S., RENNER, S., SGANZERLA, C., PRASS, G., ELY, G. J., SALVI, L. C., DAMETTO N. \& PÉRICO, E. 2018a. Checklist of Odonata (Insecta) in the state of Rio Grande do Sul, Brazil with seven new records. Biota Neotropica. 18(4):e20180551. https://doi.org/10.1590/1676-0611bn-2018-0551 (last access on 24/12/2020).

DUFRENE, M. \& LEGENDRE, P. 1997. Species assemblages and indicator species: the need a for a flexible asymmetrical approach. Ecol. Monogr. 67(3):345-366.

DUTRA, S. \& DE MARCO, P. 2015. Bionomic differences in odonates and their influence on the efficiency of indicator species of environmental quality. Ecol. Indic. 49:132-142.

FERREIRA-PERUQUETTI, P. \& DE MARCO, P. 2002. Efeito da alteração ambiental sobre comunidades de Odonata em riachos de Mata Atlântica de Minas Gerais, Brasil. Rev. Bras. Zool. 19(2):317-327.

FULAN, J. Â., HENRY R. \& DAVANSO, R. C. S. 2011. Effects of daily changes in environmental factors on the abundance and richness of Odonata. Acta Limnol. Bras. 23(1):23-29.

GARRISON, R. W., VON ELLENRIEDER, N. \& LOUTON, J. A. 2006. Damselfly Genera of The New World: an illustrated and annotated key to the Anisoptera. The John Hopkins University Press, Baltimore.

GARRISON, R. W., VON ELLENRIEDER, N. \& LOUTON, J. A. 2010. Damselfly Genera of The New World: an illustrated and annotated key to the Zygoptera. The John Hopkins University Press, Baltimore.

GOERTZEN, D. \& SUHLING, F. 2013. Promoting dragonfly diversity in cities: major determinants and implications for urban pond design. J. Insect Conserv. 17(2):399-409.

GOERTZEN, D. \& SUHLING, F. 2019. Urbanization versus other land use: Diverging effects on dragonfly communities in Germany. Divers. Distrib. 25(1):38-47.

HAMER, A. J. \& MCDONNELL, M. J. 2008. Amphibian ecology and conservation in the urbanising world: a review. Biol. Conserv. 141(10):2432-2449.

HARABIŠ, F. \& DOLNÝ, A. 2015. Necessity for the conservation of drainage systems as last refugia for threatened damselfly species, Coenagrion ornatum. Insect Conserv. Diver. 8(2):143-151.

HECKMAN, C. W. 2006. Encyclopedia of South American Aquatic Insects: Odonata - Zygoptera. Springer, Dordrecht.

HECKMAN, C. W. 2008. Encyclopedia of South American Aquatic Insects: Odonata - Anisoptera. Springer, Dordrecht.

HILL, M. J., BIGGS, J., THORNHILL, I., BRIERS, R. A., GLEDHILL, D, G., WHITE, J. C., WOOD, P. J. \& HASSAL, C. 2016. Urban ponds as an aquatic biodiversity resource in modified landscapes. Global Change Biol. 23(3):986-999.

JEANMOUGIN, M., LEPRIEUR, F., LOÏS, G. \& CLERGEAU, P. 2014. Finescale urbanization affects Odonata species diversity in ponds of a megacity (Paris, France). Acta Oecol. 59:26-34.

JUEN, L., OLIVEIRA-JUNIOR, J. M. B., SHIMANO, Y., MENDES, T. P. \& CABETTE, H. S. R. 2014. Composição e riqueza de Odonata (Insecta) em riachos com diferentes níveis de conservação em um ecótone CerradoFloresta Amazônica. Acta Amazon. 44(2):223-233.

KALKMAN, V. J., CLAUSNITZER, V., DIJKSTRA, K. D. B., ORR, A. G., PAULSON, D. R. \& VAN TOL, J. 2008. Global diversity of dragonflies (Odonata) in freshwater. In Freshwater animal diversity assessment. Springer, Dordrecht, p.351-363.

KUINCHTNER, A. \& BURIOL, G. A. 2001. Clima do Estado do Rio Grande do Sul segundo a classificação climática de Köppen e Thornthwaite. Discip. Sci., Ser. cienc. Nat. Tecnol. 2(1):171-182.
LENCIONI, F. A. A. 2005. The damselflies of Brazil: An illustrated identification guide 1 - non-Coenagrionidae families. All Print Editora, São Paulo.

LENCIONI, F. A. A. 2006. The damselflies of Brazil: An illustrated identification guide 2 - Coenagrionidae. All Print Editora, São Paulo.

LOPES, E. B., RUIZ, T. C. D. \& ANJOS, F. A. 2018. A ocupação urbana no Litoral Norte do Rio Grande do Sul, Brasil, e suas implicações no turismo de segunda residência. urbe, Rev. Bras. Gest. Urbana 10(2):426-441.

MCDONALD, R. I., KAREIVA, P. \& FORMAN, R. T. T. 2008. The implications of current and future urbanization for global protected areas and biodiversity conservation. Biol. Conserv. 141(6):1695-1703.

MCINTYRE, N. E., RANGO, J., FAGAN, W. F. \& FAETH, S. H. 2001. Ground arthropod community structure in a heterogeneous urban environment. Landscape Urban Plan. 52(4):257-274.

MCKINNEY, M. 2002. Urbanization, Biodiversity, and Conservation: The impacts of urbanization on native species are poorly studied, but educating a highly urbanized human population about these impacts can greatly improve species conservation in all ecosystems. BioScience 52(10):883-890.

MCKINNEY, M. 2008. Effects of urbanization on species richness: a review of plants and animals. Urban Ecosyst. 11(2):161-176.

MCKINNEY, M. L. \& LOCKWOOD, J. L. 1999. Biotic homogenization: a few winners replacing many losers in the next mass extinction. Trends Ecol. Evol. 14(11):450-453.

MIGUEL, T. B., OLIVEIRA-JUNIOR, J. M. B., LIGEIRO, R. \& JUEN, L. 2017. Odonata (Insecta) as a tool for the biomonitoring of environmental quality. Ecol. Indic. 81(1):555-566.

MONTEIRO-JÚNIOR, C. S., JUEN, L. \& HAMADA, N. 2014. Effects of urbanization on stream habitats and associated adult dragonfly and damselfly communities in central Brazilian Amazonia. Landscape Urban Plan. 127:28-40.

MONTEIRO-JÚNIOR, C. S., JUEN, L. \& HAMADA, N. 2015. Analysis of urban impacts on aquatic habitats in the central Amazon basin: Adult odonates as bioindicators of environmental quality. Ecol. Indic. 48:303-311.

MORAES, C. A. R. 2007. Contribuição para a gestão da zona costeira do Brasil: elementos para uma geografia do litoral brasileiro. Annablume, São Paulo.

MUZÓN, J., RAMOS, L. S. \& DEL PALACIO, A. 2019. Urban Aquatic Insects. In Aquatic Insects (Del-Claro, K. \& R. Guillermo, eds). Springer, Cham, p.349-364.

OKSANEN, J. F., BLANCHET, G., FRIENDLY, M., KINDT, R., LEGENDRE, P., MCGLINN, D., MINCHIN, P. R., O'HARA, R. B., SIMPSON, G. L., SOLYMOS, P., STEVENS, M. H. H., SZOECS E. AND WAGNER, H. 2019. vegan: Community Ecology Package. R package version 2.56 . Available from: https://CRAN.R-project.org/package=vegan.

OLAYA, M. 2019. Odonatos en Latinoamérica: la riqueza de nuestra región. Hetaerina 1:4-5.

OLIVEIRA-JUNIOR, J. M. B., SHUMANO, Y., GARDNER, T. A., HUGHES, R. M., DE MARCO, P. \& JUEN, L. 2015. Neotropical dragonflies (Insecta: Odonata) as indicators of ecological condition of small streams in the eastern Amazon. Austral Ecol. 40(6):733-744.

PRESCOTT, V.A. \& EASON, P. K. 2018. Lentic and lotic odonate communities and the factors that influence them in urban versus rural landscapes. Urban Ecosyst. 21(4):737-750.

RENNER, S., PÉRICO, E., DALZOCHIO, M. S. \& SAHLÉN, G. 2018. Water body type and land cover shape the dragonfly communities (Odonata) in the Pampa biome, Rio Grande do Sul, Brazil. J. Insect Conserv. 22(1):113-125.

RENNER, S., PÉRICO, E., DALZOCHIO, M. S. \& SAHLÉN, G. 2019. Ecoregions within the Brazilian Pampa biome reflected in Odonata species assemblies. Austral Ecol. 44(3):461-472.

RENNER, S., SAHLÉN, G. \& PÉRICO, E. 2016. Testing dragonflies as species richness indicators in a fragmented subtropical Atlantic forest environment. Neotrop. Entomol. 45(3):231-239.

ROBERTS, D. W. 2012. Labdsv: ordination and multivariate analysis for ecology. R. package version 1.5.0. Available from: http://cran.r-project.org/web/ packages/labdsv/index.html (last access 15/06/2017). 
ROSSATO, M. S. 2011. Os Climas no Rio Grande do Sul: Variabilidade, Tendências e Tipologia. Tese de doutorado, Instituto de Geociências, UFRGS, Porto Alegre.

SAMWAYS, M. J. \& STEYTLER, N. S. 1996. Dragonfly (Odonata) distribution patterns in urban and forest landscapes, and recommendations for riparian management. Biol. Conserv. 78(3):279-288.

SCHORR, M. \& PAULSON, D. 2019. World Odonata List. Tacoma, Washington, USA. Available from: https://www.pugetsound.edu (last access 10/12/2018).

SOARES FILHO, B. S. 1998. Modelagem da Dinâmica de Paisagem de uma Região de Fronteira de Colonização Amazônica. Tese de doutorado, Escola Politécnica da Universidade de São Paulo, São Paulo.

STROHAECKER, T. M. 2007. A urbanização no Litoral Norte do Estado do Rio Grande do Sul: contribuição para a gestão urbana ambiental do município de Capão da Canoa. Tese de doutorado, Instituto de Geociências, Universidade Federal do Rio Grande do Sul, Porto Alegre.

TAIT, C. J., DANIELS, C. B. \& HILL, R. S. 2005. Changes in species assemblages within the Adelaide metropolitan area, Australia, 1836-2002. Ecol. Appl. 15(1):346-359.
R CORE TEAM. 2019. A language and environment for statistical computing. Vienna, Austria: R Foundation for Statistical Computing; 2012. Available from: https://www.R-project.org.

TURNER, M. G. \& GARDNER, R. H. 2001. Landscape ecology in theory and practice. Springer, New York.

VILLALOBOS-JIMÉNEZ, G., DUNN, A. M. \& HASSALL, C. 2016. Dragonflies and damselflies (Odonata) in urban ecosystems: A review. Eur. J. Entomol. 113:217-232.

VON ELLENRIEDER, N. 2009. Databasing dragonflies: state of knowledge in the Neotropical region. Agrion 13(2):58-72.

Willigalla, C. \& FARTMANN, T. 2012. Patterns in the diversity of dragonflies (Odonata) in cities across Central Europe. Eur. J. Entomol. 109(2):235-245

Received: 08/09/2020

Revised: 24/12/2020

Accepted: 04/01/2021

Published online: 01/02/2021 